\title{
Astrocytomas and the ABO Blood Groups
}

\author{
R. R. STRANG, D. TOVI, and J. LOPEZ \\ Neurosurgical Clinic, Karolinska Hospital, Stockholm, Sweden
}

In view of the different results obtained in reported investigations of the blood group distributions of patients having astrocytomas, it was decided to analyse a large group of Swedish patients.

Mayr, Diamond, Levine, and Mayr (1956) found that there was no significant difference between the blood group distributions of 385 astrocytoma patients and a control series. Yates and Pearce (1960) analysed 473 cases, according to the year in which the diagnosis was made and the age of the patients. Amongst patients diagnosed before 1946, the blood groups were distributed normally, while amongst those diagnosed after 1945, there was a very significant reduction of group $O(p=0.0002)$. This reduction primarily occurred in children and young adults (patients born after 1930). Gaisford and Campbell (1958) in a small number of patients also found a reduction of blood group $\mathrm{O}$, and an excess of group $\mathrm{A}$. Selverstone and Cooper (I96I) analysed I39 patients, and found a highly significant decrease in blood groups $O$ and $B$, that is, in those patients with a serum anti-A factor.

\section{Material and Method}

The first 200 cases diagnosed after the year 1940, and the first 700 diagnosed after the year 1955, were included in the present investigation. The classification of Kernohan was used, so that the astrocytomas (Grades I-4) include what may be diagnosed elsewhere as glioblastoma multiforme (astrocytomas, Grades 3 and 4). Only tumours lying in the cerebral hemispheres were considered, thus excluding the cerebellar groups which have certain features suggesting that an independent evaluation is desirable. Of the 900 patients having a cerebral astrocytoma there were 546 males $(61 \%)$ and 354 females $(39 \%)$.

The control figures were obtained from the extensive survey carried out by Beckman (1959), who studied

Received May 6, 1966. donor, conscript, and paternity groups. The latteris which he considered the most reliable for statisticat purposes, has been used in the Table.

\section{Results}

The blood group distributions were analyse according to both the age and sex of the patients The Table shows the distribution by sex. Wherp

\section{TABLE}

ABO BLOOD GROUP DISTRIBUTION OF 900 PATIENTS WITH A CEREBRAL ASTROCYTOMA

\begin{tabular}{|c|c|c|c|c|c|}
\hline \multirow{2}{*}{ Patient Material } & \multicolumn{4}{|c|}{ Blood Groups } & \multirow{2}{*}{ Totals } \\
\hline & $\mathbf{A}$ & AB & B & $\mathbf{O}$ & \\
\hline \multicolumn{6}{|l|}{$\begin{array}{l}\text { Beckman's control } \\
\text { material }\end{array}$} \\
\hline $\begin{array}{c}\text { Number } \\
\text { Per cent } \\
\text { Astrocytomacases } \\
\text { Males }\end{array}$ & $\begin{array}{r}4939 \\
47 \cdot 2\end{array}$ & $\begin{array}{r}504 \\
4 \cdot 8\end{array}$ & $\begin{array}{l}1040 \\
10 \cdot 0\end{array}$ & $\begin{array}{r}3974 \\
38 \cdot 0\end{array}$ & $\begin{array}{r}10,457 \\
100 \cdot 0\end{array}$ \\
\hline $\begin{array}{l}\text { Number } \\
\text { Per cent } \\
\text { Females }\end{array}$ & $\begin{array}{l}290 \\
53 \cdot 1\end{array}$ & $\begin{array}{l}21 \\
3 \cdot 9\end{array}$ & $\begin{array}{l}49 \\
8 \cdot 9\end{array}$ & $\begin{array}{l}186 \\
34 \cdot 1\end{array}$ & $\begin{array}{c}546 \\
100 \cdot 0\end{array}$ \\
\hline $\begin{array}{l}\text { Number } \\
\text { Per cent } \\
\text { Total cases }\end{array}$ & $\begin{array}{r}169 \\
47 \cdot 7\end{array}$ & $\begin{array}{l}14 \\
4 \cdot 0\end{array}$ & $\begin{array}{l}32 \\
9 \cdot 0\end{array}$ & $\begin{array}{r}139 \\
39 \cdot 3\end{array}$ & $\begin{array}{c}354 \\
100 \cdot 0\end{array}$ \\
\hline $\begin{array}{l}\text { Number } \\
\text { Per cent }\end{array}$ & $\begin{array}{l}459 \\
51 \cdot 0\end{array}$ & $\begin{array}{l}35 \\
3 \cdot 9\end{array}$ & $\begin{array}{l}81 \\
9 \cdot 0\end{array}$ & $\begin{array}{l}325 \\
36 \cdot 1\end{array}$ & $\begin{array}{l}900 \\
100 \cdot 0\end{array}$ \\
\hline
\end{tabular}

all patients, or females alone, were considered, thet results showed that there was no essential difference between the blood group distributions of patients with astrocytomas and the controls $(p>0.05)^{\circ}$ However, when male patients alone (546) wereo considered, there was a significant excess of group $A \omega$ $(\mathrm{p}<0.05)$, but not for the other blood groups

When the blood group distributions wereo analysed according to the age of the patients, and市 the year of diagnosis, there was no significant ${ }^{\infty}$ difference between the results of those born before? . and after 1930, or in those diagnosed after 1945, and before 1946 . 


\section{Summary}

A statistical analysis of the ABO blood groups of 900 patients having a cerebral astrocytoma indicated that if all patients, or if females alone, were considered, there was no essential difference between the tumour and control groups.

When 546 male patients were evaluated independently, it was found that there was a significant excess of blood group A $(p<0.05)$.

\section{REFERENCES}

Beckman, L. (1959). A contribution to the physical anthropology and population genetics of Sweden: variations of the $A B O$, $\mathrm{Rh}, \mathrm{MN}$ and $\mathrm{P}$ blood groups. Hereditas (Lund), $45, \mathrm{pt}$. I

Gaisford, W., and Campbell, A. C. P. (1958). A.R. Brit. Emp. Cancer Campgn, 36, (2), 533.

Mayr, E., Diamond, L. K., Levine, R. P., and Mayr, M. (1956). Suspected correlation between blood-group frequency and pituitary adenomas. Science, 124, 932.

Selverstone, B., and Cooper, D. R. (I96I). Astrocytomas and ABO blood groups. F. Neurosurg., 18, 602 .

Yates, P. O., and Pearce, K. M. (I960). Recent change in bloodgroup distribution of astrocytomas. Lancet, $1,194$. 